\title{
Interaction of Vasopressin and Prostaglandins in the Toad Urinary Bladder
}

\author{
Joseph E. Bisordi, Detlef SChlondorfF, and RichaRd M. Hays, \\ Division of Nephrology, Department of Medicine, Albert Einstein College \\ of Medicine, Bronx, New York 10461
}

\begin{abstract}
A B S T RACT Prostaglandins are important modulators of the action of vasopressin. Other researchers have proposed that vasopressin stimulates prostaglandin synthesis, completing a negative feedback loop and thereby limiting vasopressin's antidiuretic effect. We have re-examined this question, using specific radioimmunoassay and thin-layer radiochromatography to determine prostaglandin synthesis by the toad bladder. Under control conditions, the bladder synthesizes prostaglandin $(\mathrm{PG}) \mathrm{E}_{2}$ and thromboxane $(\mathrm{TX}) \mathrm{B}_{2}$. There was no evidence for synthesis of $\mathrm{PGE}_{1}$ or $\mathrm{PGF}_{2 \alpha}$ by radioimmunoassay, or of other prostaglandins by radiochromatography. Furthermore, there was no evidence for metabolism of $\mathrm{PGE}_{2}$ by the bladder. Using a variety of protocols, in isolated epithelial cells as well as intact bladders, we were unable to detect any significant increase in $\mathrm{PGE}_{2}$ or $\mathrm{TXB}_{2}$ synthesis after stimulation with arginine vasopressin (AVP) or deamino-8-D-arginine vasopressin (DDAVP).
\end{abstract}

Arachidonic acid, the specific precursor of prostaglandin synthesis, increased $\mathrm{PGE}_{2}$ synthesis twofold, and significantly inhibited AVP- and DDAVP-stimulated water flow by 60 and $75 \%$, respectively. Naproxen and acetaminophen inhibited prostaglandin synthesis and enhanced water flow in response to AVP and DDAVP (44-54\%).

Our findings indicate that the toad bladder produces two prostaglandins, $\mathrm{PGE}_{2}$ and $\mathrm{TXB}_{2}$, and that vasopressin does not alter their rate of synthesis. Because agents such as acetaminophen and naproxen inhibit prostaglandin synthesis and enhance vasopressin- and DDAVP-stimulated water flow, we suggest that it is the inhibitory effect of these agents on the hormoneindependent rate of prostaglandin synthesis that is responsible for their enhancement of water flow.

A preliminary report of portions of this work was presented at the 12th Annual Meeting of the American Society of Nephrology, Boston, Mass., November 1979.

Received for publication 10 March 1980 and in revised form 21 July 1980.
Furthermore, because AVP appears to increase prostaglandin synthesis by the intact kidney, we suggest that cells other than those of the collecting tubule are responsible for the increased prostaglandin production.

\section{INTRODUCTION}

Arginine vasopressin $(\mathrm{AVP})^{1}$ increases the osmotic water flow across the mammalian collecting tubule and the toad urinary bladder (1). There is strong evidence that this response can be influenced by prostaglandins. Specifically, administration of exogenous prostaglandin $(\mathrm{PG}) \mathrm{E}_{1}$ or $\mathrm{E}_{2}$ can markedly inhibit the response of the toad bladder (2-4) and isolated collecting tubule (5) to AVP. Inhibition of endogenous prostaglandin synthesis by cyclo-oxygenase inhibitors, on the other hand, enhances the response to AVP, both in vitro in toad bladder (3) and in vivo in animals $(6,7)$ and man (6).

Zusman et al. (8) have proposed that coincident with its effect on water permeability, vasopressin stimulates prostaglandin biosynthesis, completing a negative feedback system. This proposal is based on their findings of increased PGE synthesis in vasopressintreated toad bladders as measured by means of an indirect radioimmunoassay system. This concept is not easily reconciled with several other studies or with our present results, however. Earlier studies by Wong et al. (9) reported that AVP did not increase toad bladder PGE production as measured by bioassay. Several recent reports using a variety of in vitro systems have suggested that it is the pressor rather than the antidiuretic activity of vasopressin that affects prostaglandin synthesis in rat renomedullary interstitial cells (10) and isolated perfused rabbit kidney (11). Deamino8-D-arginine vasopressin (DDAVP), the nonpressor, highly antidiuretic analogue of AVP, did not stimulate

\footnotetext{
${ }^{1}$ Abbreviations used in this paper: AVP, arginine vasopressin; DDAVP, deamino-8-D-arginine vasopressin; i, immunoreactive; PG, prostaglandin; TX, thromboxane.
} 
prostaglandin synthesis in these systems, however (10, 11). Studies on rats with congenital diabetes insipidus have shown increases in urinary prostaglandin excretion in response to DDAVP $(12,13)$, whereas DDAVP does not increase urinary $\mathrm{PGE}_{2}$ excretion in human central diabetes insipidus $(14,15)$. The possibility remains that chronic administration of DDAVP may stimulate prostaglandin synthesis in the mammalian collecting tubule either directly or indirectly, through, for example, changes in medullary composition or blood flow. Although not entirely clear, these data thus raise the possibility that it is not the primary antidiuretic activity of vasopressin on the collecting tubule, but rather its pressor activity elsewhere in the kidney or secondary phenomena, that stimulate renal prostaglandin synthesis. This concept is in contrast to the one proposed by Zusman et al. (8), which suggested that vasopressin stimulates prostaglandin synthesis as an integral part of its antidiuretic activity in the toad bladder, an analogue of the mammalian collecting tubule.

We have reexamined prostaglandin synthesis in both the whole toad bladder and isolated epithelial cells, the vasopressin target cells, using specific radioimmunoassays and thin-layer radiochromatography. Our results confirm that the toad bladder produces $\mathrm{PGE}_{2}$ and thromboxane (TX)A . Neither AVP nor DDAVP produced any change in prostaglandin synthesis, however, whereas agents that caused inhibition and stimulation of endogenous prostaglandin synthesis caused marked alterations in the water permeability response. We therefore propose an alternate hypothesis to characterize the interrelations among vasopressin, water permeability, and prostaglandins in the toad bladder that is not dependent on hormonal stimulation of prostaglandin synthesis. Our results also support the concept that the in vivo increase in prostaglandin synthesis with AVP administration is the result of the hormone's pressor activity, probably on the renal interstitial cells. Finally, the possibility remains that vasopressin may indirectly influence prostaglandin synthesis and excretion through changes in medullary solute composition or blood flow.

\section{METHODS}

Water flow studies. Female Dominican toads (Bufo marinus, National Reagents, Bridgeport, Ct.) were doubly pithed, glass bungs were tied onto both hemibladders in situ, and the hemibladders were excised. Care was taken to assure that the paired hemibladders were of equal size. Paired hemibladders were then randomly assigned to control or experimental groups. Eleven pairs of hemibladders prepared in this manner were blotted dry and weighed; mean weights for the control and experimental hemibladders corresponded closely $(132 \pm 16$ vs. $134 \pm 16 \mathrm{mg})$. Bladders were then washed three times, on the outside with amphibian phosphate-buffered Ringer's solution $\left(120 \mathrm{mM} \mathrm{Na}^{+}, 4 \mathrm{mM} \mathrm{K}^{+}, 0.5 \mathrm{mM} \mathrm{Ca}^{++}, 116\right.$

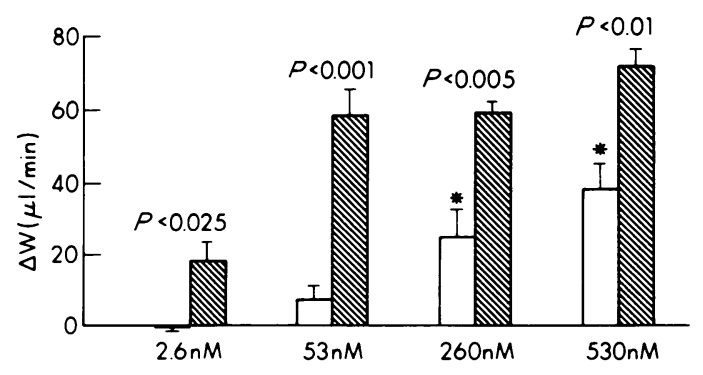

FIGURE 1 Increment in osmotic water flow $(\Delta W)$ in microliters per minute above base-line values measured over 30 min in paired hemibladders exposed to equimolar concentrations of AVP (hatched bars) and DDAVP (open bars). Values are mean $\pm S E M$ of experiments in five pairs of hemibladders for $530 \mathrm{nM}$ and seven pairs for each of the remaining concentrations of hormone. $P$ values above bars refer to comparisons of AVP and DDAVP. *, DDAVP response significantly greater than base-line water flow $(P<0.05)$.

$\mathrm{mM} \mathrm{Cl}-, 5 \mathrm{mM}$ phosphate, $230 \mathrm{mosmol} / \mathrm{kg}, \mathrm{pH} 7.4$ ), and on the inside with Ringer's diluted 1:10 with distilled water. The hemibladders were finally filled with $6 \mathrm{ml}$ of 1:10 Ringer's and suspended in a bath of $15 \mathrm{ml}$ full-strength Ringer's. The preparations were continuously aerated by bubbling a steady stream of compressed air through the serosal bath. Osmotic water flow was determined gravimetrically (14). After a 15-min equilibration period, water flow was measured over a single 30 -min basal period. Basal water flows were comparable in control and experimental hemibladders in all the studies reported. This was followed by the addition of AVP (Sigma Chemical Co., St. Louis, Mo.) or a solution of crystalline DDAVP (gift of Dr. J. Cort, Mt. Sinai School of Medicine, New York) to the serosal bath as appropriate, and the determination of osmotic water flow over the next 30 min (poststimulation period). In preliminary experiment, the osmotic water flow response to equimolar concentrations of AVP and DDAVP was tested over the range from 2.6 to $530 \mathrm{nM}$ (corresponding to $1-200 \mathrm{mU} / \mathrm{ml}$ of AVP) (Fig. 1). For the remainder of our studies we chose concentrations of $130 \mathrm{nM}$ for DDAVP and $13 \mathrm{nM}$ for AVP, concentrations that produced consistent submaximal water flow responses of approximately equal magnitude $(33.7 \pm 3.2$ vs. $39.5 \pm 3.0 \mu \mathrm{l} / \mathrm{min}$, respectively, $P$ not significant, $n=24$, unpaired data). In those experiments in which the effects of naproxen (Syntex Laboratories, Inc., Palo Alto, Calif.), acetaminophen (Sigma Chemical Co.), or arachidonic acid (Sigma Chemical Co.) were tested, these agents were present in the serosal solutions during the entire experiment (equilibration, basal, and poststimulation periods). Arachidonic acid (purity 99\%) was stored under nitrogen in the dark at $-20^{\circ} \mathrm{C}$. Aliquots of the stock solution were then placed in the serosal beakers, dried under nitrogen, and then resuspended in $15 \mathrm{ml}$ Ringer's. Mixing was ensured by placing the beakers in a sonic bath (Ultramet III, Beuhler Ltd., Evanston, Ill.). These solutions were allowed to remain at room temperature for $30 \mathrm{~min}$ to permit conversion of the arachidonic acid to the salt. All solutions used in these studies were prepared fresh daily.

Determination of prostaglandin synthesis in intact bladders. In those experiments in which prostaglandin synthesis was measured, the serosal baths were changed to fresh solutions between each period. At the end of each period, an aliquot of the serosal bath was removed and either assayed for prostaglandin on the same day or immediately frozen and stored at $-20^{\circ} \mathrm{C}$ until the day of the assay. No differ- 
ences were noted in the results when samples were assayed immediately or frozen and assayed up to $4 \mathrm{wk}$ later.

Determination of immunoreactive $P G E_{2}$ and $T X B_{2}$ synthesis by epithelial cells. In these experiments, doubly pithed toads were perfused until bloodless (about $15 \mathrm{~min}$ ) by means of intracardiac instillation of Ringer's with the liver edge cut. Bladders were then excised and washed three times inside and outside in regular Ringer's solution. Epithelial cell suspensions were obtained by scraping the mucosal surface with a glass coverslip (15). The epithelial cells from both hemibladders were pooled and kept at $4^{\circ} \mathrm{C}$ for $60 \mathrm{~min}$, then washed in Ringer's, centrifuged, and then resuspended in $5 \mathrm{ml}$ fresh Ringer's at room temperature. Previous studies from this and other laboratories have shown that epithelial cells prepared in this manner retain morphologic integrity and vasopressin sensitivity (16-18). 1-ml aliquots of these homogenous suspensions were immediately placed in test tubes containing $1 \mathrm{ml}$ of either Ringer's alone (control), AVP (26 $\mathrm{nM})$, DDAVP $(260 \mathrm{nM})$, arachidonic acid $(10 \mu \mathrm{M})$, or naproxen $(100 \mu \mathrm{M})$. These suspensions were incubated for $15 \mathrm{~min}$ at $20^{\circ} \mathrm{C}$ in a shaking water bath $(40$ cycles $/ \mathrm{min})$, and then immediately cooled to $4^{\circ} \mathrm{C}$ and centrifuged at 1,000 $\mathrm{rpm}$ for $2 \mathrm{~min}$. The supernatant solution was removed, immediately frozen, and stored at $-20^{\circ} \mathrm{C}$ until assayed for immunoreactive (i) $\mathrm{PGE}_{2}$ and $\mathrm{TXB}_{2}$. The pellet was dissolved in $0.1 \mathrm{~N} \mathrm{NaOH}$ and protein content was determined by the method of Lowry et al. (19).

Radioimmunoassay for prostaglandins and thromboxane. ${ }_{i P G E}$, iPGE $_{1}$, and $\mathrm{iPGF}_{2 \alpha}$ content was measured by the radioimmunoassay method of Dray et al. (20), using specific antisera supplied by Boehringer Mannheim Biochemicals, Indianapolis, Ind., or the Institut Pasteur, Paris, France. Antisera from these two sources had identical cross-reactivities and binding constants, and yielded comparable standard curves. Cross-reactivity (at $\mathrm{B} / \mathrm{B}_{0}=0.5$ ) for the $\mathrm{PGE} \mathrm{E}_{2}$ antisera was $3.2 \%$ with $\mathrm{PGE}_{1}, 0.02 \%$ with $\mathrm{PGA}_{2}, 0.01 \%$ with $\mathrm{PGF}_{2 \alpha}, 0.15 \%$ with 13,14 -dihydroPGE, $0.11 \%$ with $13,14-$ dihydro-15-ketoPGE ${ }_{2}$, and $0.01 \%$ with $\mathrm{PGB}_{2}$. Cross-reactivity (at $\mathrm{B} / \mathrm{B}_{0}=0.5$ ) for the $\mathrm{PGE}_{1}$ antisera was $15 \%$ with $\mathrm{PGE}_{2}$, $0.03 \%$ with $\mathrm{PGA}_{2}, 0.05 \%$ with $\mathrm{PGF}_{2 \alpha}$, and $<0.00001 \% \mathrm{PGB}_{2}$. Cross-reactivity (at $\mathrm{B} / \mathrm{B}_{0}=0.5$ ) for the $\mathrm{PGF}_{2 \alpha}$ antisera was $0.25 \%$ with $\mathrm{PGE}_{1}, 0.15 \%$ with $\mathrm{PGE}_{2}$, and $<0.1 \%$ with $\mathrm{PGA}_{2}$ and $\mathrm{PGB}_{2}$.

$\mathrm{iTXB}_{2}$, the stable metabolite of TXA same technique using a specific antiserum supplied by Seragen, Inc., Boston, Mass. Cross-reactivity for this antiserum (at $\mathrm{B} / \mathrm{B}_{0}=0.5$ ) was $2.52 \%$ with $\mathrm{PGD}_{2}, 0.26 \%$ with $\mathrm{PGE}_{2}, 0.07 \%$ with $\mathrm{PGF}_{2 \alpha}, 0.05 \%$ with 6 -ketoPGF $F_{1 \alpha}$, and $<0.05 \%$ with $\mathrm{PGA}_{2}$.

Final antibody titer was $1 / 4,000$ for anti-TXB $, 1 / 5,000$ for anti-PGE $, 1 / 36,000$ for anti-PGF $2 \alpha$, and 1/54,000 for anti$\mathrm{PGE}_{1}(20)$. Standard solutions were prepared from authentic prostaglandins (gift of Dr. J. Pike, Upjohn Co., Kalamazoo, Mich.). $\left[{ }^{3} \mathrm{H}\right] \mathrm{PGE}_{2},\left[{ }^{3} \mathrm{H}\right] \mathrm{PGF}_{2 \alpha},\left[{ }^{3} \mathrm{H}\right] \mathrm{PGE}_{1}$, and $\left[{ }^{3} \mathrm{H}\right] \mathrm{TXB}_{2}$ were obtained from New England Nuclear, Boston, Mass. (specific activities $130,120,89.5$, and $150 \mathrm{Ci} / \mathrm{mmol}$, respectively).

All determinations were performed in duplicate on 100 $\mu l$ aliquots. Intra-assay variability was $<5 \%$ ( $n=12$ for $\mathrm{PGE}_{2}$ and $n=20$ for $\mathrm{TXB}_{2}$ ). To minimize interassay variability (5$10 \%$ ), paired control and experimental samples were tested in the same assay ( $n=30$ for iPGE and $n=20$ for iTXB $_{2}$ ). In preliminary experiments, no difference was noted between results of direct radioimmunoassay and lipid extraction followed by radioimmunoassay. Because of the highly specific antisera used, therefore, we chose to perform radioimmunoassay on unextracted samples. This procedure also avoids any problems with recovery or chemical interconversion of prostaglandins during the extraction process (21).
Serial dilution of samples revealed that radioimmunoassayable prostaglandins decreased in proportion to the degree of dilution up to dilutions of 1:50 (the greatest dilution tested). In a series of preliminary experiment, known amounts of $\mathrm{PGE}_{2}$ (100 and $25 \mathrm{pg} / 100 \mu \mathrm{l}$ serosal medium) were added to the serosal medium of naproxen-treated hemibladders in the presence and absence of AVP (13 nM). Subsequent radioimmunoassay for $\mathrm{PGE}_{2}$ revealed values virtually identical to those predicted $(96 \pm 1$ and $25 \pm 2 \mathrm{pg} /$ $100 \mu l, n=9$ and 6 , respectively). Radioimmunoassay of the arachidonic acid-containing solution revealed $0.01 \%$ crossreactivity with the $\mathrm{PGE}_{2}$ antiserum. Therefore, $\mathrm{iPGE}_{2}$ activity was measured in aliquots of the exogenous arachidonic acidcontaining solutions, and these blank values were subtracted from the values obtained for $\mathrm{iPGE}_{2}$ synthesis in the presence of bladder tissue.

In experiments with intact bladders, prostaglandin synthesis was determined by measuring the concentration of prostaglandin present in the serosal bath at the end of a 30 -min period and was expressed as picomoles of prostaglandin per minute per hemibladder. Prostaglandin synthesis by epithelial cells was determined by measuring the appearance of prostaglandin in the incubation medium during a 15-min period and was expressed as picomoles of prostaglandin per minute per milligram protein in the incubation. Over the range of protein content per incubation (0.09-0.55 $\mathrm{mg}$ protein/incubation), $\mathrm{iPGE}_{2}$ synthesis was linearly correlated with protein concentration $(r=0.911$, linear regression analysis, $n=8$ ).

The minimal detectable amounts of the various prostaglandins in the radioimmunoassay were $P \mathrm{PE}_{1}$ or $\mathrm{PGE}_{2}$, 1-2 pg; $\mathrm{TXB}_{2}, 1 \mathrm{pg}$; and $\mathrm{PGF}_{2 \alpha}, 5 \mathrm{pg} / 0.1-\mathrm{ml}$ sample aliquot. For the intact bladder studies, these correspond to synthetic rates of $\sim 0.015-0.03 \mathrm{pmol} / \mathrm{min}$ per hemibladder for $\mathrm{PGE}_{1}$ or $\mathrm{PGE}_{2}, \sim 0.015 \mathrm{pmol} / \mathrm{min}$ per hemibladder for $\mathrm{TXB}_{2}$, and $\sim 0.08$ $\mathrm{pmol} / \mathrm{min}$ per hemibladder for $\mathrm{PGF}_{2 \alpha}$

Determination of prostaglandin synthesis from exogenous $\left[1-{ }^{14} \mathrm{C}\right]$ arachidonic acid in intact bladders. After an initial 15-min equilibration period, paired hemibladders $(n=4)$ were incubated in either Ringer's alone or in naproxen $(100$ $\mu \mathrm{M}) .30 \mathrm{~min}$ later the serosal baths were changed to fresh beakers in which $2 \mu \mathrm{Ci}$ of $\left[1-{ }^{14} \mathrm{C}\right]$ arachidonic acid (New England Nuclear, specific activity $36.5 \mathrm{mCi} / \mathrm{mmol}$ ) in toluenemethanol (9:1) was dried under nitrogen and resuspended in Ringer's or Ringer's containing naproxen $(100 \mu \mathrm{M})$. Aliquots of serosal media were then removed at 0 and $30 \mathrm{~min}$. These samples were immediately acidified to $\mathrm{pH} 3.0-3.5$ with $1 \mathrm{~N}$ $\mathrm{HCl}$; crystalline $\mathrm{NaCl}$ was added and then extracted twice in an equal volume of ethyl acetate. The aqueous layer was discarded and the organic layer evaporated to dryness under a stream of nitrogen. The sides of the tubes were washed down with ethyl acetate and spotted along with authentic standard solutions of arachidonic acid, $\mathrm{PGE}_{2}, \mathrm{TXB}_{2}$, and $\mathrm{PGA}_{2}$ on precoated, silica gel 60 thin-layer chromatography plates (E. Merck Reagents, Elmsford, N. Y.). The plates were developed in solvent system I (the organic phase of ethyl acetate:glacial acetic acid:iso-octane: $\mathrm{H}_{2} \mathrm{O}$ [11:1:5:10]) or solvent system II (chloroform:methanol:acetic acid: $\mathrm{H}_{2} \mathrm{O}$ [98:8: $1: 0.8])$. Standards were identified by iodine staining. Sample lanes were cut into 5-mm strips, immersed in liquid scintillation cocktail (National Diagnostics, Inc., Somerville, N. J.), and radioactivity determined by liquid scintillation counting.

Metabolism of exogenous $\left[{ }^{3} \mathrm{H}\right] P G E_{2}$. Paired hemibladders were incubated for $30 \mathrm{~min}$ in a serosal bath containing $1 \mu \mathrm{Ci}$ $\left[5,6,8,11,12,14,15-{ }^{3} \mathrm{H}(N)\right] \mathrm{PGE}_{2}$ (specific activity $130 \mathrm{Ci} / \mathrm{mmol}$, New England Nuclear), with experimental bladders receiving AVP (13 nM) as well ( $n=2$ pairs). Aliquots of the serosal media of these incubations and of a solution of $\left[{ }^{3} \mathrm{H}\right] \mathrm{PGE}_{2}$ in 
Ringer's were then acidified, extracted, and processed by thin-layer chromatography in solvent system I, as described above.

Determination of prostaglandin synthesis from exogenous $\left[{ }^{14} \mathrm{C}\right]$ arachidonic acid in epithelial cell suspensions. Epithelial cell suspensions were prepared as above. Equal volumes of the resuspended cells were incubated for $30 \mathrm{~min}$ in either regular Ringer's or Ringer's containing naproxen $(100 \mu \mathrm{M})$. The suspensions were then centrifuged, the supernatant solutions discarded, and the pellets resuspended in Ringer's or Ringer's plus naproxen. The suspensions were then placed in test tubes containing $0.5 \mu \mathrm{Ci}\left[{ }^{14} \mathrm{C}\right]$ arachidonic acid. The suspensions were incubated for $30 \mathrm{~min}$ at $20^{\circ} \mathrm{C}$ in a shaking bath (40 cycles/min), then cooled to $4^{\circ} \mathrm{C}$ and centrifuged at $1,000 \mathrm{rpm}$ for $2 \mathrm{~min}$. The supernatant solution was immediately removed and acidified, and aliquots were processed for thin-layer chromatography in solvent system I, II, or III (diethyl ether:methanol:acetic acid [90:1:2]).

Determination of AVP's effects on arachidonic acid release and prostaglandin synthesis in bladders pretreated with radiolabeled arachidonic acid. Paired hemibladders were incubated overnight $(18 \mathrm{~h})$ in Ringer's containing glucose $(5 \mathrm{mM})$, penicillin $(100 \mathrm{U} / \mathrm{ml})$, streptomycin $(100 \mathrm{U} / \mathrm{ml})$, and $\left[1{ }^{14} \mathrm{C}\right]$ arachidonic acid $(n=4$ pairs). A total of $1 \mu \mathrm{Ci}$ of $\left[{ }^{14} \mathrm{C}\right]$ arachidonic acid was added to each serosal bath and 0.4 $\mu \mathrm{Ci}$ to each mucosal bath. The bladders were then washed three times by replacing the serosal and mucosal baths every 30 min with Ringer's and Ringer's diluted 1:10 with distilled $\mathrm{H}_{2} \mathrm{O}$, respectively. Nonincorporated ${ }^{14} \mathrm{C}$-labeled products were removed with the initial bath and first wash (98\% of the total nonincorporated counts removed). Counts appearing in the second and third wash reached a plateau. After a third washing, the baths were changed again, and AVP (13 nM) was added to the serosal bath of the experimental hemibladder. Total radioactivity of the serosal and mucosal solutions was determined before and after the 18-h incubation, at the end of each wash, and at the end of the experimental period. Water flow was measured over $30 \mathrm{~min}$. At the end of the experimental period, the serosal solutions were removed, $10 \mathrm{ml}$ extracted, and thin-layer radiochromatography performed in solvent system II. Recovery of ${ }^{14} \mathrm{C}$ label was $70-80 \%$ for both control and experimental solutions during the extraction process. At the end of the experiment the bladders were emptied, blotted dry inside and out, and dissolved in $5 \mathrm{ml}$ of $1 \mathrm{~N} \mathrm{NaOH}$; radioactivity was then counted.

An identical series of experiments ( $n=4$ pairs) was performed using $\left[5,6,8,9,11,12,14,15-{ }^{3} \mathrm{H}(N)\right]$ arachidonic acid with $4 \mu \mathrm{Ci}$ added to the serosal bath and $1 \mu \mathrm{Ci}$ added to the mucosal bath of each hemibladder (specific activity 62 $\mathrm{Ci} / \mathrm{mmol}$, New England Nuclear).
All values are expressed as the means \pm the standard error of the mean. In intact bladder studies, the results in one hemibladder are compared with those in the paired hemibladder by the method of paired analysis (22). Results in epithelial cell suspensions are compared by the same method.

\section{RESULTS}

Effects of naproxen, acetaminophen, and arachidonic acid on water flow. We first investigated the effects of stimulation and inhibition of prostaglandin synthesis on the osmotic water flow response to DDAVP and AVP. Incubation of experimental hemibladders with the prostaglandin synthetase inhibitor naproxen $(100 \mu \mathrm{M})$ did not affect basal water flows compared with control hemibladders incubated in Ringer's alone $(2.1 \pm 0.2$ vs. $2.2 \pm 0.3 \mu \mathrm{l} / \mathrm{min}$, respectively). Addition of AVP (13 $\mathrm{nM}$ ) resulted in a $54 \%$ greater osmotic water flow response in naproxentreated hemibladders $(58.7 \pm 4.2 \mu \mathrm{l} / \mathrm{min})$ compared with the paired control hemibladders $(38.0 \pm 2.8 \mu \mathrm{l} / \mathrm{min}$, $P<0.005, n=6)$. In another series of experiments, naproxen $(100 \mu \mathrm{M})$ resulted in a similar degree of enhancement in the response to DDAVP (130 nM) (Table I).

We next investigated the effects of acetaminophen on basal and DDAVP-stimulated water flow. Acetaminophen has been reported to enhance the response to AVP in toad bladder $(23,24)$ and have antidiuretic activity in human central diabetes insipidus (25). Recently this compound has been found to inhibit prostaglandin synthesis in rat renal medullary slices (26).

In our studies, treatment of bladders with acetaminophen $(300 \mu \mathrm{M})$ led to a response similar to that seen with naproxen. Basal water flow was not affected. The water flow in response to $130 \mathrm{nM}$ DDAVP was $25.9 \pm 3.1 \mu \mathrm{l} / \mathrm{min}$ in control hemibladders and 37.2 $\pm 3.5 \mu \mathrm{l} / \mathrm{min}$ in acetaminophen-treated bladders, a $44 \%$ enhancement (Table I).

To determine whether the effects of naproxen and acetaminophen were additive, paired hemibladders were incubated in naproxen $(100 \mu \mathrm{M})$ and the experi-

TABLE I

Effects of Naproxen and Acetaminophen on Basal and DDAVP-stimulated Osmotic Water Flow

\begin{tabular}{|c|c|c|c|c|c|c|c|}
\hline \multicolumn{2}{|c|}{ Agents added } & \multirow[b]{2}{*}{$n$} & \multicolumn{2}{|c|}{ Basal } & \multicolumn{2}{|c|}{ Post-DDAVP (130 nM) } & \multirow[b]{2}{*}{$P$} \\
\hline Control & Experimental & & Control & Experimental & Control & Experimental & \\
\hline & & & \multicolumn{2}{|c|}{$\mu l / \min$} & \multicolumn{2}{|c|}{$\mu \mathrm{l} / \mathrm{min}$} & \\
\hline - & Naproxen $(100 \mu \mathrm{M})$ & 10 & $2.4 \pm 0.3$ & $2.4 \pm 0.5$ & $38.9 \pm 6.0$ & $56.1 \pm 6.2$ & $<0.001$ \\
\hline \multirow{3}{*}{ Naproxen $(100 \mu \mathrm{M})$} & Acetaminophen $(300 \mu \mathrm{M})$ & 12 & $2.1 \pm 0.2$ & $1.9 \pm 0.2$ & $25.9 \pm 3.1$ & $37.2 \pm 3.5$ & $<0.001$ \\
\hline & Acetaminophen $(300 \mu \mathrm{M})$ & & & & & & \\
\hline & naproxen $(100 \mu \mathrm{M})$ & 6 & $2.2 \pm 0.4$ & $2.4 \pm 0.3$ & $46.7 \pm 5.1$ & $46.0 \pm 5.6$ & \\
\hline
\end{tabular}

Naproxen and acetaminophen were added to the serosal baths $15 \mathrm{~min}$ before the basal period. Basal water flow was measured over $30 \mathrm{~min}$ followed by the addition of DDAVP $(130 \mathrm{nM})$ and measurement of water flow over the next 30 min. $P$ values refer to the comparison of DDAVP-stimulated water flow in the control and experimental hemibladders. 
TABLE II

Effects of Arachidonic Acid on Basal and Hormone-stimulated Osmotic Water Flow

\begin{tabular}{|c|c|c|c|c|c|c|}
\hline & \multirow[b]{2}{*}{$n$} & \multicolumn{2}{|c|}{ Basal } & \multicolumn{2}{|c|}{ Hormone-stimulated } & \multirow[b]{2}{*}{$P$} \\
\hline & & Control & $\begin{array}{l}\text { Arachidonic } \\
\text { acid }(10 \mu \mathrm{M})\end{array}$ & Control & $\begin{array}{l}\text { Arachidonic } \\
\text { acid }(10 \mu \mathrm{M})\end{array}$ & \\
\hline & & \multicolumn{2}{|c|}{$\mu l / \min$} & \multicolumn{2}{|c|}{$\mu l / \min$} & \\
\hline $\operatorname{AVP}(13 \mathrm{nM})$ & 3 & $2.3 \pm 0.2$ & $2.1 \pm 0.7$ & $44.3 \pm 5.0$ & $18.5 \pm 7.1$ & $<0.05$ \\
\hline DDAVP (130 nM) & 6 & $2.0 \pm 0.2$ & $1.9 \pm 0.2$ & $25.8 \pm 3.3$ & $6.6 \pm 2.2$ & $<0.001$ \\
\hline
\end{tabular}

Arachidonic acid (10 $\mu \mathrm{M})$ was added to the serosal baths of experimental hemibladders $15 \mathrm{~min}$ before the basal period. Basal water flow was measured over a 30-min period followed by addition of hormone (13 $\mathrm{nM} \mathrm{AVP} \mathrm{or} 130 \mathrm{nM}$ DDAVP) to control and experimental hemibladders. Hormone-stimulated water flow was then measured over the next $30 \mathrm{~min}$. $P$ values refer to the comparison of hormone-stimulated water flow in control and arachidonic acid-treated hemibladders.

mental hemibladders were treated with acetaminophen $(300 \mu \mathrm{M})$ as well. Basal water flows were comparable in the two groups. There was no significant difference in the water flow response to $130 \mathrm{nM}$ DDAVP between the two groups (Table I). Thus, acetaminophen would appear to share a common mechanism of action with naproxen in the toad bladder.

Arachidonic acid $(10 \mu \mathrm{M})$, the specific precursor of prostaglandins, was administered to experimental hemibladders to stimulate endogenous prostaglandin production. Basal water flow was not affected. However, the response to DDAVP (130 $\mathrm{nM}$ ) and AVP (13 $\mathrm{nM}$ ) was markedly inhibited by administration of arachidonic acid $(10 \mu \mathrm{M})$ (Table II).

Prostaglandin synthesis in intact bladders. Using specific radioimmunoassay for $\mathrm{iPGE}_{2}, \mathrm{iPGE}_{1}$, and $\mathrm{iPGF}_{2 \alpha}$, we determined the rates of synthesis of these various prostaglandins in intact bladders. No prostaglandins could be detected in the mucosal medium. Neither iPGE ${ }_{1}$ nor iPGF $_{2 \alpha}$ could be detected in the serosal medium in the basal state or after stimulation with AVP or DDAVP. Synthesis of $\mathrm{iPGE}_{2}$ was 2.72 $\pm 0.32 \mathrm{pmol} / \mathrm{min}$ per hemibladder under basal conditions, and increased to $5.96 \pm 0.63 \mathrm{pmol} / \mathrm{min}$ per hemibladder in the presence of arachidonic acid $(10 \mu \mathrm{M})$, the specific precursor of $\operatorname{PGE}_{2}(P<0.005)$ (Table III).

Incubation with naproxen $(100 \mu \mathrm{M})$ decreased basal iPGE $_{2}$ synthesis to levels $<0.07 \mathrm{pmol} / \mathrm{min}$ per hemibladder (Table III). Acetaminophen $(300 \mu \mathrm{M})$ inhibited basal iPGE ${ }_{2}$ synthesis by $60 \%$ compared with paired control hemibladders $(P<0.05)$ (Table III), thus confirming that acetaminophen acts as an inhibitor of prostaglandin synthesis in toad bladder.

We next investigated the effects of AVP and DDAVP on iPGE $_{2}$ synthesis. AVP (13 nM) failed to produce a significant increase in $\mathrm{PCE}_{2}$ synthesis compared with control $(2.1 \pm 0.4$ vs. $1.6 \pm 0.4 \mathrm{pmol} / \mathrm{min}$ per hemibladder, respectively) (Table III). DDAVP also failed to increase $\mathrm{iPGE}_{2}$ synthesis. Synthesis of $\mathrm{iPGE}_{2}$ was $0.8 \pm 0.1 \mathrm{pmol} / \mathrm{min}$ per hemibladder in tissue exposed to DDAVP ( $130 \mathrm{nM}$ ), compared with $0.9 \pm 0.1 \mathrm{pmol} /$ min per hemibladder in controls (Table III). The differences in control values between these experiments most likely relate to different batches of toads used in the different sets of experiments.

Experiments performed in an identical manner but using bicarbonate-buffered Ringer's $(90 \mathrm{mM}$ sodium chloride, $25 \mathrm{mM}$ sodium bicarbonate, $1 \mathrm{mM}$ calcium chloride, $0.5 \mathrm{mM}$ potassium dihydrogen phosphate, $0.5 \mathrm{mM}$ magnesium sulfate, and $5 \mathrm{mM}$ glucose gassed with $97 \% \mathrm{O}_{2}-3 \% \mathrm{CO}_{2}$ ) instead of phosphate-buffered Ringer's also revealed no evidence for stimulation of iPGE $_{2}$ synthesis in response to AVP (13 nM) (0.8 \pm 0.2 in controls vs. $0.7 \pm 0.1 \mathrm{pmol} / \mathrm{min}$ per hemibladder in AVP-treated bladders, $n=6, P>0.2$ ). All other studies were performed in phosphate Ringer's. To

TABLE III

Synthesis of iPGE $_{2}$ by Toad Bladders

\begin{tabular}{lrccc}
\hline \multirow{2}{*}{$\begin{array}{c}\text { Experimental agents } \\
\text { added }\end{array}$} & $n$ & Control & Experimental & $P$ \\
\cline { 3 - 4 } & & \multicolumn{2}{c}{ pmol/min/hemibladder } \\
\hline $\begin{array}{c}\text { Arachidonic acid } \\
(10 \mu \mathrm{M})\end{array}$ & 9 & $2.72 \pm 0.32$ & $5.96 \pm 0.63$ & $<0.005$ \\
$\begin{array}{l}\text { Naproxen } \\
\quad(100 \mu \mathrm{M})\end{array}$ & 3 & $1.79 \pm 0.80$ & $<0.07$ & $<0.01$ \\
$\begin{array}{c}\text { Acetaminophen } \\
(300 \mu \mathrm{M})\end{array}$ & 6 & $1.60 \pm 0.37$ & $0.65 \pm 0.11$ & $<0.05$ \\
$\begin{array}{c}\text { AVP }(13 \mathrm{nM}) \\
\text { DDAVP }\end{array}$ & 12 & $1.62 \pm 0.37$ & $2.11 \pm 0.44$ & $>0.1$ \\
$\quad(130 \mathrm{nM})$ & 15 & $0.91 \pm 0.12$ & $0.79 \pm 0.11$ & $>0.3$ \\
\hline
\end{tabular}

Synthesis of $\mathrm{iPGE}_{2}$ in experimental hemibladders is compared with simultaneous values for $\mathrm{iPGE}_{2}$ in the paired control hemibladders. 
determine whether the failure to observe a stimulation of prostaglandin synthesis by AVP might be secondary to high basal $\mathrm{iPGE}_{2}$ production, we measured basal iPGE $_{2}$ synthesis over 30 -min periods up to $2 \mathrm{~h}$. Synthesis of $\mathrm{iPGE}_{2}$ decreased progressively with time from $1.60 \pm 0.26$ to $1.30 \pm 0.10$ to $0.71 \pm 0.12$ to 0.06 $\pm 0.06 \mathrm{pmol} / \mathrm{min}$ per hemibladder for the four successive 30 -min periods $(n=13)$. Even with the low levels reached after $2 \mathrm{~h}$, however, addition of AVP (13 $\mathrm{nM}$ ) did not alter iPGE $_{2}$ synthesis compared with paired control hemibladders $(0.06 \pm 0.06$ vs. $0.06 \pm 0.05 \mathrm{pmol} /$ min per hemibladder, respectively, $n=4$ ).

Prostaglandin synthesis from exogenous $\left[{ }^{14} \mathrm{C}\right]$ arachidonic acid in the toad bladder. To determine whether prostaglandins other than $\mathrm{PGE}_{2}$ are produced by the bladders or whether the bladders metabolize prostaglandins, we investigated the conversion of exogenous $\left[{ }^{14} \mathrm{C}\right]$ arachidonic acid ( $n=4$ pairs). Incubation of intact bladders with $\left[{ }^{14} \mathrm{C}\right]$ arachidonic acid for $30 \mathrm{~min}$, followed by acid extraction of the serosal baths and thinlayer chromatography in solvent system $\mathrm{I}$, revealed a broad peak of ${ }^{14} \mathrm{C}$-labeled prostaglandins, which was completely suppressed by naproxen (Fig. 2). This peak corresponds to the standards for $\mathrm{PGE}_{2}$ and $\mathrm{TXB}_{2}$, which comigrate in this solvent system. In solvent system II, which allows separation of $\mathrm{PGE}_{2}$ and $\mathrm{TXB}_{2}$, three separate peaks of ${ }^{14} \mathrm{C}$-labeled prostaglandins appeared, corresponding to the authentic standards of $\mathrm{PGE}_{2}, \mathrm{TXB}_{2}$, and $\mathrm{PGA}_{2}$. It should be noted that in solvent system I, $\mathrm{PGA}_{2}$ migrates close to arachidonic acid, so that small amounts of $\left[{ }^{14} \mathrm{C}\right] \mathrm{PGA}_{2}$ would not be clearly separated from the large peaks of unreacted $\left[{ }^{14} \mathrm{C}\right]$ arachidonic acid. Thus the only prostaglandins identified were $\mathrm{PGE}_{2}, \mathrm{TXB}_{2}$, and $\mathrm{PGA}_{2}$.

Metabolism of exogenous $\left[{ }^{3} \mathrm{H}\right] P G E_{2}$ by intact bladders. We considered the possibility that AVP might accelerate the metabolism of $\mathrm{PGE}_{2}$ into a substance not measurable by specific assay for $\mathrm{iPGE}_{2}$, and thereby obscure any hormonal stimulation of $\mathrm{PGE}_{2}$ synthesis. To test this possibility, we incubated paired hemibladders with exogenous $\left[{ }^{3} \mathrm{H}\right] \mathrm{PGE}_{2}$ in the presence or absence of AVP (13 nM). Acid extraction and thinlayer chromatography (solvent system I) of the serosal medium from both control and AVP-treated bladders yielded identical radiochromatograms. The ${ }^{3} \mathrm{H}$ label appeared exclusively in two peaks, a major one $(75 \%)$ corresponding to $\mathrm{PGE}_{2}$ and a minor one $(25 \%)$ corresponding to $\mathrm{PGA}_{2}$. An identical pattern was seen when the experiment was carried out in the absence of bladder tissue, indicating that the $\mathrm{PGA}_{2}$ seen represents an artifact of the extraction procedure (21). The ratio of $\mathrm{PGA}_{2}: \mathrm{PGE}_{2}$ was identical in all instances regardless of whether bladder tissue or AVP was present.

Prostaglandin synthesis in scraped epithelial cells. It was possible that our studies in intact bladders did

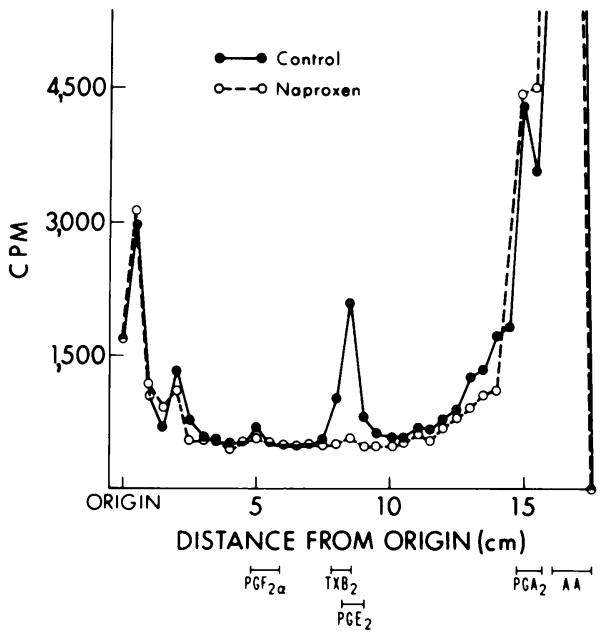

Figure 2 Representative thin-layer radiochromatogram of the acid lipid extracts of serosal baths from paired hemibladders incubated for $30 \mathrm{~min}$ with exogenous $\left[{ }^{14} \mathrm{C}\right]$ arachidonic acid in the presence (open circles) and absence (filled circles) of naproxen (100 $\mu \mathrm{M})$. Migration of authentic lipid standards is shown along the abscissa. Developed in solvent system I. For details see Methods. AA, arachidonic acid.

not accurately reflect prostaglandin synthesis in the vasopressin-sensitive target cell, the epithelial cell. For example, the $\mathrm{TXB}_{2}$ seen might have represented production by platelets trapped in blood vessels in the bladder wall. We therefore investigated prostaglandin synthesis in suspensions of scraped epithelial cells from bladders perfused free of blood before scraping. This eliminates any contribution to prostaglandin synthesis by the supporting layers of the bladders or the formed elements of blood (e.g., platelets).

Incubation of scraped epithelial cells with $\left[{ }^{14} \mathrm{C}\right]-$ arachidonic acid $(n=4)$ yielded results comparable to those shown for the intact bladder in Fig. 2. Acid extraction and thin-layer chromatography in Solvent Systems I, II, and III revealed ${ }^{14} \mathrm{C}$-labeled $\mathrm{TXB}_{2}$, $\mathrm{PGE}_{2}$, and $\mathrm{PGA}_{2}$ as the only prostaglandin peaks. No peaks comigrating with $\mathrm{PGE}_{2}$ metabolites (e.g., 15keto-13,14-dihydroPGE ${ }_{2}$ ) were observed.

These findings were confirmed by radioimmunoassay determination of prostaglandin synthesis in epithelial cells. Under control conditions, epithelial cells produced $2.69 \pm 0.24 \mathrm{pmol} \mathrm{iPGE}_{2} / \mathrm{min}$ per $\mathrm{mg}$ protein and $0.85 \pm 0.22 \mathrm{pmol} \mathrm{iTXB}_{2} / \mathrm{min}$ per $\mathrm{mg}$ protein (Table IV). Incubation with arachidonic acid $(10 \mu \mathrm{M})$ increased both $\mathrm{iPGE}_{2}$ and $\mathrm{iTXB}_{2}$ synthesis by $120 \%$, whereas naproxen $(100 \mu \mathrm{M})$ inhibited iPGE $_{2}$ synthesis by $34 \%$ and $\mathrm{iTXB}_{2}$ synthesis by $38 \%$ (Table IV). Neither AVP (13 nM) nor DDAVP (130 nM) altered epithelial cell $\mathrm{iPGE}_{2}$ or $\mathrm{iTXB}_{2}$ synthesis compared with control values (Table IV), confirming the results obtained in whole bladders (Table III). 
TABLE IV

Synthesis of $i P G E_{2}$ and $\mathrm{iTXB}_{2}$ by Toad Bladder Epithelial Cells

\begin{tabular}{lccccc}
\hline & Control & $\begin{array}{c}\text { AVP } \\
(13 \mathrm{nM})\end{array}$ & $\begin{array}{c}\text { DDAVP } \\
(130 \mathrm{nM})\end{array}$ & $\begin{array}{c}\text { Arachidonic acid } \\
(10 \mu \mathrm{M})\end{array}$ & $\begin{array}{c}\text { Naproxen } \\
(100 \mu \mathrm{M})\end{array}$ \\
\hline iPGE $_{2}$ (pmol/min/mg protein) & $2.69 \pm 0.24$ & $2.63 \pm 0.19$ & $2.41 \pm 0.18$ & $5.91 \pm 0.82$ & $1.77 \pm 0.13$ \\
$P$ & & $\mathrm{NS}$ & $\mathrm{NS}$ & $<0.01$ & $<0.001$ \\
$\mathrm{iTXB}_{2}$ (pmol/min/mg protein) & $0.85 \pm 0.22$ & $0.87 \pm 0.25$ & $0.77 \pm 0.16$ & $1.89 \pm 0.28$ & $0.53 \pm 0.10$ \\
$P$ & & $\mathrm{NS}$ & $\mathrm{NS}$ & $<0.0005$ & $<0.05$ \\
\hline
\end{tabular}

Homogenous suspensions of scraped epithelial cells were incubated in Ringer's (control), AVP (13 $\mathrm{nm})$, DDAVP $(130 \mathrm{nM})$, arachidonic acid $(10 \mu \mathrm{M})$, or naproxen $(100 \mu \mathrm{M})$ for $15 \mathrm{~min}$ at $21^{\circ} \mathrm{C}$ in a shaking water bath. Suspensions were then immediately placed on ice, centrifuged, and the supernatant solutions removed and assayed for $\mathrm{iPGE}_{2}$ and $\mathrm{iTXB}_{2} . n=8$.

Effects of AVP on prostaglandin synthesis in bladders prelabeled with $\left[{ }^{14} \mathrm{C}\right]$ arachidonic acid and $\left[{ }^{3} \mathrm{H}\right]$ arachidonic acid. Because of the failure to observe increased $\mathrm{iPGE}_{2}$ and $\mathrm{iTXB}_{2}$ synthesis after AVP stimulation, we examined the effect of AVP on prostaglandin synthesis in bladders prelabeled (overnight) with either $\left[{ }^{14} \mathrm{C}\right]-$ or $\left[{ }^{3} \mathrm{H}\right]$ arachidonic acid.

After washing the bladders free of nonincorporated $\left[{ }^{14} \mathrm{C}\right]$ arachidonic acid, $50 \pm 4 \%$ of the label remained incorporated in the hemibladders. Addition of AVP $(13 \mathrm{nM})$ to these prelabeled hemibladders resulted in a significant increase in water flow compared with control $(43.3 \pm 7.5$ vs. $4.8 \pm 3.3 \mu \mathrm{l} / \mathrm{min}, P<0.025)$, indicating that the bladders responded normally. Total ${ }^{14} \mathrm{C}$ released into the mucosal solution during the experimental period was comparable in the control and AVP-treated hemibladders $(1,280 \pm 110$ vs. 1,250 $\pm 260 \mathrm{cpm}$, respectively). Release of ${ }^{14} \mathrm{C}$ into the serosal bath during the experimental period was also not significantly different between the control and AVPtreated hemibladders $(4,570 \pm 500$ vs. $4,020 \pm 300 \mathrm{cpm})$. Thin-layer radiochromatography of the extracted serosal solutions was performed in Solvent System II. As shown in Fig. 3, there was no difference in the release of $\left[{ }^{14} \mathrm{C}\right]$ arachidonic acid, $\left[{ }^{14} \mathrm{C}\right] \mathrm{PGE}_{2},\left[{ }^{14} \mathrm{C}\right] \mathrm{TXB}_{2},\left[{ }^{14} \mathrm{C}\right]-$ $\mathrm{PGA}_{2}$, or ${ }^{14} \mathrm{C}$-neutral lipids between the control or hormone-treated bladders. Thus, there was no evidence of an effect of AVP on either release of $\left[{ }^{14} \mathrm{C}\right]$ arachidonic acid or synthesis of ${ }^{14} \mathrm{C}$-labeled prostaglandins in prelabeled bladders.

In contrast, Zusman et al. (8) reported that AVP caused a 40-fold increase in the release of total counts and arachidonic acid, with a proportionate increase in the synthesis of $\mathrm{PGE}_{2}$ in bladders prelabeled with $\left[{ }^{3} \mathrm{H}\right]$ arachidonic acid. To determine whether this discrepancy with our results might be due to differences in the radiolabel used, we repeated our prelabeling experiments using $\left[{ }^{3} \mathrm{H}\right]$ arachidonic acid and a protocol comparable to the one used by Zusman et al. (8). Paired hemibladders incorporated comparable amounts of the $\left[{ }^{3} \mathrm{H}\right]$ arachidonic acid $(480,160 \pm 68,000$ and $454,620 \pm 48,750 \mathrm{cpm})$. Total counts released during the experimental period were also not significantly different in the control and AVP-treated hemibladders $(4,190 \pm 748$ vs. $5,190 \pm 730 \mathrm{cpm})$. Water

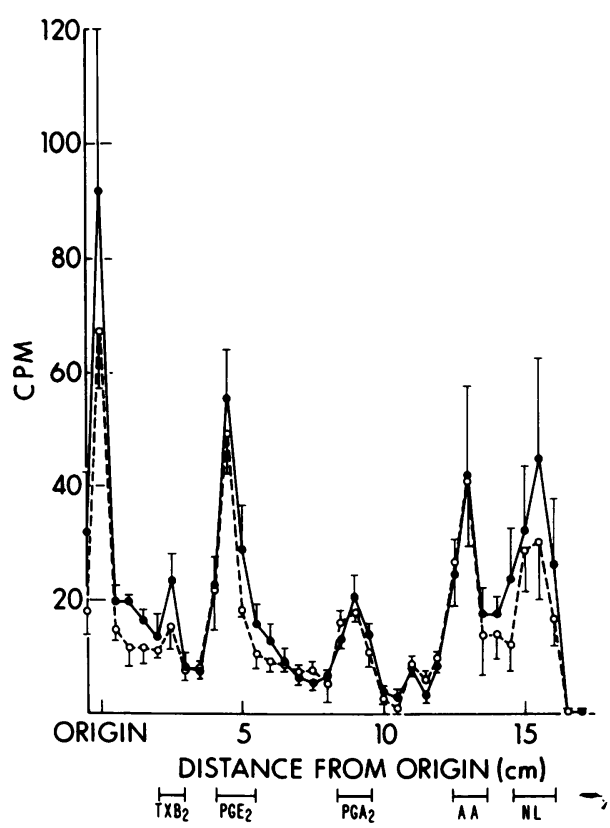

FIGURE 3 Thin-layer radiochromatogram of the acid lipid extracts of serosal baths from prelabeled toad bladders. Hemibladders were prelabeled overnight with $\left[1-{ }^{14} \mathrm{C}\right]$ arachidonic acid and then washed free of nonincorporated ${ }^{14} \mathrm{C}$ labeled products. After the third washing, the baths were changed again, and AVP (13 nM) was added to the serosal bath of the experimental hemibladders. At the end of the 30-min experimental period, the serosal solutions were removed and processed for thin-layer radiochromatography. For details refer to Methods. Each point represents the mean \pm SEM under control (filled circles, solid line) or AVPtreated (open circles, dashed line) conditions for four pairs of hemibladders. Migration of authentic lipid standards is shown along the abscissa. Results are expressed as counts per minute corrected for machine background. AA, arachidonic acid. NL, neutral lipids. 
flow was significantly increased in the AVP-treated hemibladders compared with control $(48.7 \pm 9.2$ vs. $1.9 \pm 0.3 \mu \mathrm{l} / \mathrm{min}, P<0.025)$. Thin-layer radiochromatography of the serosal medium showed a similar pattern of radiolabeled products, as shown for the ${ }^{14} \mathrm{C}$-label experiments in Fig. 3, with peaks corresponding to the $\mathrm{TXB}_{2}, \mathrm{PGE}_{2}, \mathrm{PGA}_{2}$, arachidonic acid, and neutral lipid standards. Table $\mathrm{V}$ gives the results for the radiolabel comigrating with the corresponding standards from control and AVP-treated hemibladders. There were no significant differences in either prostaglandin or arachidonic acid release between control and experimental hemibladders.

\section{DISCUSSION}

Our studies demonstrate that the toad urinary bladder, and specifically its vasopressin-sensitive cell, the epithelial cell, produces two prostaglandins, $\mathrm{PGE}_{2}$ and $\mathrm{TXB}_{2}$. This has been confirmed by two independent techniques, radioimmunoassay and thin-layer radiochromatography. Furthermore, there is no evidence that AVP or DDAVP stimulates prostaglandin synthesis as measured by either technique.

Based on these results, we propose an alternate hypothesis to characterize the interrelation of vasopressin, water permeability, and prostaglandins in this tissue. In this scheme, it is the basal rate of endogenous prostaglandin synthesis that modulates the water flow response to vasopressin. In the absence of vasopressin, prostaglandins have no effect on water permeability. Also, vasopressin does not initiate any negative feedback response via increases in prostaglandin synthesis, as has been proposed in the past (8).

The present studies support this alternate hypothesis. Toad bladders, and specifically the epithelial cells, synthesize $\mathrm{PGE}_{2}$ and thromboxane as determined by radioimmunoassay and thin-layer chromatography. Extrapolation of the data from epithelial cell incubation indicates that these cells account for most, if not all, of the iPGE ${ }_{2}$ synthesis in the whole bladder. Inhibition of basal prostaglandin synthesis by the cyclooxygenase inhibitor naproxen markedly enhances the water flow response to vasopressin without affecting basal water flow. As with naproxen, acetaminophen also inhibited prostaglandin synthesis and enhanced hormone-stimulated, but not basal water flow. These studies demonstrate that acetaminophen acts as a prostaglandin synthesis inhibitor in toad bladders, as has been reported in renal medullary slices (26). When, on the other hand, endogenous prostaglandin synthesis was stimulated by administration of arachidonic acid, basal water flow was unaffected, but hormone-stimulated water flow was markedly inhibited. These data confirm the important role played by prostaglandins in modulating the response to vasopressin.
TABLE V

Prostaglandin Synthesis from Bladders Prelabeled with $\left[{ }^{3} \mathrm{H}\right]$ Arachidonic Acid

\begin{tabular}{cccccc}
\hline & Total counts & $\mathrm{PGE}_{2}$ & $\mathrm{PGA}_{2}$ & $\mathrm{TXB}_{2}$ & $\begin{array}{c}\text { Arachi- } \\
\text { donic } \\
\text { acid }\end{array}$ \\
\hline \multicolumn{6}{c}{} \\
Control & $1,045 \pm 85$ & $248 \pm 33$ & $81 \pm 12$ & $63 \pm 5$ & $31 \pm 7$ \\
AVP (13 & $\mathrm{NS}$ & $\mathrm{NS}$ & $\mathrm{NS}$ & $\mathrm{NS}$ & $\mathrm{NS}$ \\
$\mathrm{nM})$ & $1,278 \pm 144$ & $257 \pm 52$ & $115 \pm 23$ & $77 \pm 17$ & $50 \pm 8$ \\
\hline
\end{tabular}

Paired hemibladders $(n=4)$ were prelabeled with $\left[{ }^{3} \mathrm{H}\right]$ arachidonic acid and then incubated without (control) or with AVP (13 nM). After $30 \mathrm{~min}$, the serosal solutions were removed and processed for thin-layer radiochromatography in solvent system II. For details, refer to Methods. The values represent the mean \pm SEM for total radioactivity per plate (total counts) and for each of the radiolabeled peaks comigrating with the respective standards. Radioactivity not accounted for represents neutral lipids, hydroxyacids, phospholipids remaining at the origin, and diffuse background radioactivity.

Radioimmunoassay studies revealed that in intact bladders, iPGE $_{2}$ synthesis was not altered by AVP. Similarly, AVP had no effect on either iPGE ${ }_{2}$ or iTXB ${ }_{2}$ synthesis by isolated epithelial cells. These results were confirmed by a second, independent method, thin-layer radiochromatography. Vasopressin did not increase synthesis of labeled prostaglandins or release of labeled arachidonic acid in bladders in which the endogenous arachidonic acid pool was prelabeled with either $\left[1-{ }^{14} \mathrm{C}\right]-$ or $\left[{ }^{3} \mathrm{H}\right]$ arachidonic acid.

These findings are supported by the earlier work of Wong et al. (9), who found that vasopressin in the toad bladder had no effect on the synthesis of PGE as determined by bioassay. A recent preliminary report has failed to observe any increase in $\mathrm{iPGE}_{2}$ synthesis by vasopressin in the toad bladder (27). However, these results and ours are at odds with those of Zusman et al. (8). These workers reported that vasopressin stimulated toad bladder PGE synthesis in a dosedependent manner. At the concentration of AVP used in our study ( $13 \mathrm{nM})$, they reported a sixfold increase in iPGE synthesis. After prelabeling toad bladders with $\left[{ }^{3} \mathrm{H}\right]$ arachidonic acid, they found a 40 -fold increase in radiolabeled arachidonic acid release and a proportionate increase in radiolabeled $\mathrm{PGE}_{2}$ synthesis. Based on these results they proposed that vasopressin increased prostaglandin synthesis in the toad bladder by activating phospholipase, and thus increasing the amount of arachidonic acid available for prostaglandin synthesis. This increased prostaglandin production would in turn inhibit vasopressin's effect on water flow, thus closing a negative feedback loop. 
There are several possible explanations for the discrepancies between our results and those of other workers $(8,28)$. The first involves the differences between the radioimmunoassay systems used. These investigators measured PGE synthesis after conversion of PGE to PGB, followed by radioimmunoassay for PGB. Another report from the same laboratory (29) demonstrated that this technique greatly overestimated PGE concentrations in human urine in comparison with measurements of $\mathrm{PGE}_{2}$ by gas chromatographymass spectroscopy. This discrepancy was attributed to possible cross-reactivity of the antiserum with a PGE metabolite. However, direct measurements of $\mathrm{PGE}_{2}$ and its major urinary metabolite did not consistently account for the discrepancy. This raises the possibility of nonspecific interference with the radioimmunoassay for PGB. Therefore, results for $\mathrm{PGE}_{2}$ synthesis obtained with the PGB radioimmunoassay system must be interpreted with caution.

For a number of reasons, we feel that the radioimmunoassay for $\mathrm{PGE}_{2}$ used in the present study reflects actual $\mathrm{PGE}_{2}$ synthesis. The antiserum employed in our studies was highly specific for $\mathrm{PGE}_{2}$. Serial dilution of samples up to 1:50 revealed no evidence of nonspecific interference with antigenantibody binding. Radioimmunoassay measured virtually all of the exogenous $\mathrm{PGE}_{2}$ added to the serosal bath of bladders in which endogenous prostaglandin production was blocked by naproxen. Furthermore, this was not altered by administration of AVP. In addition, the results with administration of naproxen and arachidonic acid confirm that appropriate changes in $\mathrm{iPGE}_{2}$ synthesis can be detected with this method.

Because we employed a different buffer system than used in the previous reports $(8,28)$, we considered the possibility that this might account for the discrepancies between these reports and the present study. However, $\mathrm{iPGE}_{2}$ synthesis was not altered by AVP when we employed a bicarbonate-buffered Ringer's similar to that used by Zusman et al. (8). In the report of Burch et al. (28), bladders were allowed to equilibrate for $2 \mathrm{~h}$ before measurement of $\mathrm{iPGE}_{2}$ synthesis. As shown in the present report, $\mathrm{iPGE}_{2}$ synthesis decreased to very low levels at this time, comparable to the levels reported by Burch et al. (28). Even at these low levels, however, $\mathrm{iPGE}_{2}$ synthesis was not increased by AVP in our studies. Thus the factor of time does not appear to account for the differences between our results and those of previous reports $(8,28)$. The remainder of our studies were performed in a time frame comparable to that used by Zusman et al. (8).

We investigated another possible explanation for the difference between the present study and the previous reports. Vasopressin might stimulate synthesis of some prostaglandins other than $\mathrm{PGE}_{2}$ or
$\mathrm{TXB}_{2}$, which might be measured as PGE by the PGB assay system, but not cross-react with the specific $\mathrm{PGE}_{2}$ antiserum used in our studies. Radioimmunoassay failed to detect any $\mathrm{PGE}_{1}$ or $\mathrm{PGF}_{2 \alpha}$ in our study, however, and thin-layer radiochromatography indicated that the only labeled prostaglandins produced by the toad bladder in the presence of $\left[{ }^{14} \mathrm{C}\right]$ arachidonic acid were $\mathrm{PGE}_{2}$ and $\mathrm{TXB}_{2}$.

Although there was no evidence for the presence of $\mathrm{PGE}_{2}$ metabolites in the experiments involving $\left[{ }^{14} \mathrm{C}\right]$ arachidonic acid, we investigated the possibility that AVP might simultaneously stimulate the synthesis and metabolic breakdown of $\mathrm{PGE}_{2}$; however, there was no evidence of any metabolism of exogenous $\left[{ }^{3} \mathrm{H}\right] \mathrm{PGE}_{2}$ in either control or AVP-treated hemibladders. In addition, experiments with prelabeled bladders showed no radiolabeled prostaglandin metabolites under either control or AVP-treated conditions. These studies also demonstrate that AVP does not stimulate the release of total radiolabel, endogenous $\left[{ }^{14} \mathrm{C}\right]-$ or $\left[{ }^{3} \mathrm{H}\right]$ arachidonic acid, or its products from prelabeled bladders. These results are in marked contrast to those of Zusman et al. (8), who reported a 40-fold increase in arachidonic acid release from prelabeled bladders in response to AVP with a proportionate increase in $\mathrm{PGE}_{2}$ synthesis. As has been suggested by others (30), such large increases in arachidonate release in the absence of some method of trapping the released arachidonate (e.g., addition of albumin to the medium) are unusual, as free arachidonic acid is rapidly reincorporated into phospholipids. Clearly, our experiments provide no evidence for increased release of arachidonate or increased prostaglandin synthesis. Incomplete washing of bladders might account for the large increases in the appearance of radiolabel in the serosal medium in the study of Zusman et al. (8). If this were the case, then vasopressin-stimulated water flow across the bladders might passively wash out nonincorporated products into the serosal bath.

The present study also demonstrate that toad bladder epithelial cells produce $\mathrm{TXB}_{2} \cdot \mathrm{TXB}_{2}$ is the stable metabolite of the active but quite short-lived parent compound, $\mathrm{TXA}_{2}$. The role, if any, of TXA $\mathrm{TX}_{2}$ in modulating vasopressin's action is not clear from the present studies. An interaction of thromboxane with vasopressin has been postulated $(28,31)$. However, studies with the prostaglandin endoperoxide-thromboxane agonist (15S)-hydroxy-11 $\alpha, 9 \alpha$-(epoxymethano)prosta$5 \mathrm{Z}, 13 \mathrm{E}$-dienoic acid have revealed conflicting results. Burch and Halushka (31) demonstrated that this agent stimulated basal and vasopressin-stimulated water flow, whereas Ludens and Taylor (32) found that it inhibited vasopressin-stimulated water flow. Imidazole (1 $\mathrm{mM})$, a thromboxane synthesis inhibitor, inhibited vasopressin-stimulated water flow, but at this concentration this agent also increased $\mathrm{iPGE}_{2}$ 
synthesis (28). At higher doses $(50 \mathrm{mM})$, imidazole inhibited both $\mathrm{iTXB}_{2}$ and iPGE synthesis and enhanced vasopressin-stimulated water flow (28). Therefore, its effect cannot be clearly attributed to inhibition of thromboxane synthesis.

Our finding of $\mathrm{TXB}_{2}$ synthesis by the toad bladder confirms the recent report of Burch et al. (28); however, in contrast to these investigators we find no evidence that vasopressin increases thromboxane synthesis. The reasons for the discrepancy are not clear.

Although the results of the present study differ from those of several previous reports, there are data from a variety of systems that tend to support our concept. In vivo studies in Brattleboro rats and in man have demonstrated an increase in urinary $\mathrm{PGE}_{2}$ excretion in response to AVP administration $(12,33)$. However, results with the administration of the nonpressor analogue of AVP, DDAVP, are conflicting. Dunn et al. (12) and Walker and Frolich (13) reported an increase in urinary $\mathrm{PGE}_{2}$ excretion in Brattleboro rats given DDAVP. Two reports on human diabetes insipidus, however, failed to find any increase in urinary $\mathrm{PGE}_{2}$ excretion in response to DDAVP $(14,15)$.

A possible explanation for the conflicting results may relate to the duration of exposure to hormone. The studies demonstrating increased urinary $\mathrm{PGE}_{2}$ excretion in rats with congenital diabetes insipidus involved chronic administration of DDAVP. It may be that chronic hormonal stimulation of the collecting tubule may lead to increased prostaglandin synthesis, possibly secondary to changes in, for example, medullary composition and the attendant alterations in medullary blood flow.

Furthermore, prostaglandin synthesis in cultured renomedullary interstitial cells was stimulated by AVP but not by DDAVP (10). Similarly, pressor doses of AVP increased prostaglandin and thromboxane synthesis in isolated perfused rabbit kidney, whereas equal doses of DDAVP did not (11). These data thus raise the possibility that it is not the antidiuretic activity of vasopressin on the collecting tubule, but rather its pressor activity elsewhere in the kidney that acutely stimulates renal prostaglandin synthesis. Chronic administration of vasopressin, on the other hand, could influence medullary prostaglandin synthesis and excretion indirectly, by changing renal medullary blood flow or medullary solute composition for example. This concept is consistent with our finding that neither AVP nor DDAVP stimulates prostaglandin synthesis in the toad urinary bladder, an analogue of the mammalian renal collecting tubule.

Although our results do not support the presence in the toad bladder of a negative feedback loop in which vasopressin stimulates prostaglandin synthesis, they do support the importance of the basal rate of prostaglandin synthesis as a modulator of vasopressin's action. Clearly, factors that influence the basal rate of prostaglandin synthesis will have a marked influence on vasopressin response.

\section{ACKNOWLEDGMENTS}

This work was supported by grants from the National Institutes of Health, AM-03858 and AM-07089 (Dr. Hays), and AM-22036 (Dr. Schlondorff). Dr. Bisordi was a Research Fellow of the National Kidney Foundation during the course of these studies. Dr. Schlondorff is a recipient of an Irma T. Hirschl Career Scientist Award.

\section{REFERENCES}

1. Hays, R. M. 1976. Antidiuretic hormone and water transfer. Kidney Int. 9: 223-230.

2. Lipson, L. C., and G. W. Sharp. 1971. Effect of prostaglandin $\mathrm{E}_{1}$ on sodium transport and osmotic water flow in toad bladder. Am. J. Physiol. 220: 1046- 1052.

3. Carvounis, C. P., N. Franki, S. D. Levine, and R. M. Hays. 1979. Membrane pathways for water and solutes in the toad bladder. I. Independent activation of water and urea transport. J. Membr. Biol. 49: 253-268.

4. Orloff, J., J. S. Handler, and S. Bergstrom. 1965. Effect of prostaglandin $\left(\mathrm{PGE}_{1}\right)$ on the permeability response of the toad bladder to vasopressin, theophylline and adenosine 3',5'-monophosphate. Nature (Lond.). 205: 397-398.

5. Grantham, J. J., and J. Orloff. 1968. Effect of prostaglandin $E_{1}$ on the permeability response of the isolated collecting tubule to vasopressin, adenosine $3^{\prime}, 5^{\prime}$-monophosphate and theophylline. J. Clin. Invest. 47: 1154-1161.

6. Berl, T., A. Raz, H. Wald, J. Horowitz, and W. Czaczkes. 1977. Prostaglandin synthesis inhibition and the action of vasopressin: studies in man and rat. Am. J. Physiol. 232(6): F529-F537.

7. Anderson, R. J., T. Berl, K. M. McDonald, and R. W. Schrier. 1975. Evidence for an in vivo antagonism between vasopressin and prostaglandin in the mammalian kidney. J. Clin. Invest. 56: 420-426.

8. Zusman, R. M., H. R. Keiser, and J. S. Handler. 1977. Vasopressin-stimulated prostaglandin E biosynthesis in the toad urinary bladder. J. Clin. Invest. 60: 1339-1347.

9. Wong, P. Y. D., J. R. Bedwani, and A. W. Cuthbert. 1972. Hormone action and the levels of cyclic AMP and prostaglandins in the toad bladder. Nat. New Biol. 238: 27-31.

10. Beck, T. R., A. Hassid, and M. J. Dunn. 1979. The effect of antidiuretic hormone and an analog on prostaglandin synthesis by cultured rat renomedullary interstitial cells. Proceedings of the 4th International Prostaglandin Conference. 8. (Abstr.)

11. Zipser, R., S. Myers, and P. Needleman. 1980. Vasopressin but not deamino-vasopressin stimulates renal prostaglandins: implications of pressor activity. Clin. Res. 28: 65A. (Abstr.)

12. Dunn, M. J., H. P. Greely, H. Voltin, L. B. Kinter, and R. Beeuwkes. 1978. Renal excretion of prostaglandin $E_{2}$ and $F_{2 \alpha}$ in diabetes insipidus rats. Am. J. Physiol. 235(6): E624-E627.

13. Walker, L., and J. C. Frolich. 1979. Stimulation of renal prostaglandin synthesis by deamino-8-D-arginine vasopressin. Fed. Proc. 38(3): 420. (Abstr.)

14. Düsing, R., R. Herrmann, and H. J. Kramer. 1979. The renal prostaglandin system in central diabetes insipidus: effects of deamino-arginine vasopressin (DDAVP). Proceedings of the 4th International Prostaglandin Conference. 27-28. (Abstr.) 
15. Fichman, M., P. Zia, and R. Zipser. 1979. Contribution of urine volume to the elevated urinary prostaglandin $\mathrm{E}$ in Bartter's Syndrome, central and nephrogenic diabetes insipidus. Proceedings of the 4th International Prostaglandin Conference. 33. (Abstr.)

16. Levine, S. D., H. Weber, and D. Schlondorff. 1979. Inhibition of adenylate cyclase by general anesthetics in toad urinary bladder. Am. J. Physiol. 237: F372-F378.

17. MacKnight, A. D. C., D. R. DiBona, A. Leaf, and M. M. Civan. 1971. Measurements of the composition of epithelial cells from the toad urinary bladder. J. Membr. Biol. 6: $108-126$.

18. MacKnight, A. D. C., A. Leaf, and M. M. Civan. 1971. Effects of vasopressin on the water and ionic composition of toad bladder epithelial cells. J. Membr. Biol. 6: 127-137.

19. Lowry, O. H., N. J. Rosebrough, A. L. Farr, and R. J. Randall. 1951. Protein measurement with the Folin phenol reagent. J. Biol. Chem. 193: 265-275.

20. Dray, F., B. Charbonnel, and J. Maclouf. 1975. Radioimmunoassay of prostaglandins $F_{\alpha}, E_{1}$, and $E_{2}$ in human plasma. Eur. J. Clin. Invest. 5: 311-318.

21. Granstrom, E., and H. Kindohl. 1978. Radioimmunoassay of prostaglandins and thromboxanes. Adv. Prostaglandin Thromboxane Res. 5: 119-210.

22. Snedecor, G. W., and W. G. Cochran. 1967. Statistical Methods. The Iowa State University Press, Ames, Iowa. 91-119. 6th edition.

23. Nusynowitz, M. L., L. C. Wegienka, B. F. Bower, and P. H. Forsham. 1966. Effects on vasopressin action of analgesic drugs in vitro. Am. J. Med. Sci. 252: 424-428.

24. Lozada, E. S., J. Gouaux, N. Franki, G. B. Appel, and R. M. Hays. 1972. Studies on the mode of action of the sulfonylureas and phenylacetamides in enhancing the effect of vasopressin. J. Clin. Endocrinol. Metab. 34: 704-712.

25. Nusynowitz, M. L., and P. H. Forsham. 1966. The anti- diuretic action of acetaminophen. Am. J. Med. Sci. 252: $429-435$.

26. Zenser, T. V., M. D. Mattamal, C. A. Herman, S. Johsi, and B. B. Davis. 1978. Effect of acetaminophen on prostaglandin $E_{2}$ and prostaglandin $F_{2 \alpha}$ synthesis in the renal inner medulla of rat. Biochim. Biophys. Acta. 542: 486-495.

27. Forrest, J. N., and D. B. P. Goodman. 1980. Prostaglandin $\mathrm{E}_{2}$ mediates the effect of $\mathrm{pH}$ on ADH-stimulated water flow but $\mathrm{ADH}$ does not stimulate prostaglandin $\mathrm{E}_{2}$ production in the toad urinary bladder. Clin. Res. 28(2): 445A.

28. Burch, R. M., D. R. Knapp, and P. V. Halushka. 1979. Vasopressin stimulates thromboxane synthesis in the toad urinary bladder: effects of imidazole. J. Pharmacol. Exp. Ther. 210: 344-348.

29. Gill, J. R., J. C. Frolich, R. E. Bowden, A. A. Taylor, H. R. Keiser, H. W. Seyberth, J. A. Oates, and F. C. Bartter. 1976. Bartter's Syndrome: a disorder characterized by high urinary prostaglandins and a dependence of hyperreninemia on prostaglandin synthesis. Am. J. Med. 61: 43-51.

30. Isakson, P. C., A. Raz, W. Hseuh, and P. Needleman. 1978. Lipases and prostaglandin biosynthesis. Adv. Prostaglandin Thromboxane Res. 3: 113-120.

31. Burch, R. M., and P. V. Halushka. 1979. Thromboxane is a positive modulator of vasopressin-stimulated water flow in the toad urinary bladder. Proceedings of the 12th Annual Meeting of the American Society for Nephrology. 99A. (Abstr.)

32. Ludens, J., and C. J. Taylor. 1979. Inhibition of ADHstimulated water flow by an endoperoxide analog. Fed. Proc. 38: 1060. (Abstr.)

33. Walker, L. A., A. R. Whorton, M. Smigel, R. France, and J. C. Frolich. 1978. Antidiuretic hormone increases renal prostaglandin synthesis in vivo. Am. J. Physiol. 235(3): F180-F185. 